\title{
Strategi Pemberdayaan Masyarakat Pesisir Di Kabupaten Jember
}

\section{Coastal Community Empowerment Strategy in Jember Regency}

\author{
Kanthi Pangestuning Prapti ${ }^{1}$ \\ ${ }^{1}$ Prodi Agroteknologi Fakultas Pertanian dan Perikanan Universitas 17 Agustus 1945 Banyuwangi Jl. Adi \\ Sucipto 26 Banyuwangi, Jawa Timur \\ Email; kanthipangestuning@untag-banyuwangi.ac.id
}

Submited: 26 June 2021 Revised: 08 July 2021 Accepted: 22 July 2021 Publish: 31 July 2021

\begin{abstract}
Abstrak
Potensi tinggi dari desa pesisir Kabupaten Jember perlu ditindaklanjuti dengan program pembangunan dan pengembangan. Pemberdayaan masyarakat pesisir salah satu bentuk aktualisasi program yang tentu membutuhkan peran serta masyarakat pesisir itu sendiri dan stakeholder. Dalam konteks pemikiran tersebut, perlu komitmen kolektif pihak yang memiliki potensi sumberdaya. Tujuan dari penelitian ini adalah mengetahui potensi sumberdaya pesisir dan menentukan strategi pemberdayaan masyarakat pesisir berdasarkan potensi sumberdaya pesisir di Kabupaten Jember. Metode penelitiaan yang digunakan adalah metode deskriptif, dengan analisa data menggunakan analisa SWOT sebagai dasar dalam menentukan strategi pemberdayaan masyarakat pesisir Kabupaten Jember melalui pendekatan diskusi kelompok secara intensif (Focus Group Discussion, FGD). Hasil analisa SWOT merumuskan yaitu: 1) Peningkatan pengetahuan dan teknologi pada masyarakat tentang konsep pesisir dan pemberdayaan masyarakat (khususnya partisipasi masyarakat), 2) Perbaikan akses jalan menuju kawasan pesisir (khususnya pantai) Kabupaten Jember serta beberapa sarana prasarana untuk menunjang pengembangan ekowisata pantai, 3) Penguatan kelembagaan kelompok masyarakat sebgai langkah optimalisasi kepengurusan kelompok usaha bersama (KUB) di pesisir Kabupaten Jember, 4) Pengembangan sarana dan prasarana pelabuhan perikanan (tempat pendaratan ikan), 5) Identifikasi potensi sumberdaya pesisir dan kebutuhan masyarakat pesisir yang berkelanjutan, 6) Deliniasi kawasan pesisir antar desa dalam wilayah kecamatan, 7)Integrasi program pemberdayaan masyarakat pesisir antar stakeholder (horizontal atau vertikal).
\end{abstract}

Kata kunci: pemberdayaan masyarakat, pesisir Jember.

Abstract

The high potential of the coastal village of Jember Regency needs to be followed up with development and development programs. Empowerment of coastal communities is one form of program actualization, which requires the participation of the coastal community itself and stakeholders. In the context of this thought, collective commitment from parties with potential resources is needed. This study aims to determine the potential of coastal resources and determine the strategy of empowering coastal communities based on the potential of coastal resources in the Jember Regency. The research method used is a descriptive method, with data analysis using SWOT analysis as the basis for determining the strategy of empowering coastal communities in Jember Regency through an intensive group discussion approach (Focus Group Discussion, FGD). The results of the SWOT analysis formulate, namely: 1) Increasing knowledge and technology in the community about the concept of coastal and community empowerment (especially community participation), 2) Improvement of road access to coastal areas (especially beaches) Jember Regency as well as several infrastructure facilities to support the development of coastal ecotourism, 3) Strengthening community group institutions as a step to optimize the management of joint business groups (KUB) on the coast of Jember Regency, 4) Development of fishing port facilities and infrastructure (fish landing sites), 5) Identification of potential coastal resources and sustainable coastal community needs, 6) Delineation of coastal areas between villages within the subdistrict area, 7) Integration of coastal community empowerment programs between stakeholders (horizontally or vertically).

Keywords: community empowerment, Jember coast. 


\section{PENDAHULUAN}

Wilayah pesisir menjadi sangat penting bagi negara-negara yang mempunyai wilayah pesisir, seiring dengan perkembangan pembangunan. Sumberdaya yang terkandung di wilayah pesisir sangat beragam. Sumberdaya tersebut di kelompokkan menjadi dua kelompok, yaitu sumberdaya manusia (human resources) dan sumberdaya fisik (physical resources). Sejumlah desa pesisir di selatan Jawa Timur merupakan obyek pembangunan dan pengembangan yang seyogyanya dilaksanakan oleh pemerintah, bersama dengan masyarakat. Program pembangunan dan pengembangan yang dilakukan oleh pemerintah bersma masyarakat dapat berjalan dengan baik jika dibekali dengan data data dasar terkait potensi sumberdaya desa pesisir.

Kabupaten Jember merupakan salah satu kabupaten pesisir di selatan Jawa Timur. Jember terdiri dari 31 kecamatan, enam diantaranya merupakan kecamatan pesisir. Jumlah desa pesisir yang berada dalam enam kecamatan tersebut adalah 11 desa. Desa desa pesisir tersebut membentuk garis pantai sepanjang 115, $827 \mathrm{~km}$. Kawasan pesisir Jember dimanfaatkan untuk beberapa kepentingan, antara lain sebagai zona pelabuhan, pemukiman, industri, dan konservasi. Kawasan konservasi yang terdpat di kawasan pesisir adalah Cagar Alam Nusa Barong, dan sebagian Taman Nasional Meru Betiri. Ekosistem terumbu karang masih bisa ditemukan di beberapa lokasi, antara lain di Pantai Papuma, Bande Alit, dan Nusa Barong. Ekosistem mangrove di kawasan ini merupakan hasil rehabilitasi dan restorasi oleh masyarakat, dan membentuk green belt di sempadan pantai Kabupaten Jember.

Komoditas perikanan tangkap di pesisir Kabupaten Jember adalah ikan tuna, tongkol, dan cakalang. Potensi produk lestari komoditi tersebut adalah 40.000 ton per tahun. Nilai produksi perikanan tangkap ini diperoleh dengan beberapa jenis alat tangkap, yaitu gillnet sebanyak 565 unit, rawai dasar 1.081 unit, trammel net 2.248 unit, payang 426 unit, sel net 925 unit, dan lain-lain sebanyak 408 unit. Pariwisata yang dapat berkembang dengan baik di pesisir selatan adalaha wisata bahari, terutama wisata pantai. Kawasan pesisir selatan Kabupaten Jember telah menjadi destinasi wisata bahari yang dikunjungi 
oleh wisatawan. Destinasi wisata bahari tersebut, antara lain adalah: Pantai Payangan, Watu Ulo, Tanjung Papuma, Pantai Puger, Pantai Paseban, dan Bande Alit. Sebagian besar destinasi wisata bahari ini berada di Kecamatan Ambulu.

Potensi tinggi dari desa pesisir Kabupaten Jember ini perlu ditindaklanjuti dengan program pembangunan dan pengembangan. Pemberdayaan masyarakat pesisir salah satu bentuk aktualisasi program yang tentu membutuhkan peran serta masyarakat pesisir itu sendiri dan stakeholder. Dalam konteks pemikiran di atas, jika kegiatan pembangunan dan pemberdayaan masyarakat bertujuan mulia untuk mengembangkan kemandirian dan memanusiakan manusia, khususnya bagi masyarakat pesisir, maka sudah selayaknya komitmen kolektif pihak-pihak yang memiliki potensi sumberdaya untuk dikontribusikan, sangat diperlukan dalam memperlancar pencapaian tujuan pemberdayaan tersebut. Berdasarkan uraian diatas penelitian ini bertujuan untuk mengetahui potensi sumberdaya pesisir dan menentukan strategi pemberdayana masyarakat pesisir berdasarkan potensi di Kabupaten Jember.

\section{METODOLOGI PENELITIAN}

Penelitian dilakukan di sepanjang pesisir Kabupaten Jember, tepatnya 11 Desa di sepanjang pesisir Kabupaten Jember. Selain itu, pengambilan data juga dilakukan di Dinas Perikanan Kabupaten Jember dan focuss group discussion (FGD) dilakukan di Bappeda Kabupaten Jember. Waktu penelitian adalah September - November 2018. Metode penelitiaan yang digunakan adalah metode deskriptif, yaitu mengangkat fakta, keadaan, variabel,dan fenomena-fenomena yang terjadi saat sekarang (ketika penelitian berlangsung) dan menyajikannya apa adanya. Jenis penelitian deskriptif yang digunakan adalah studi survei.

Penelitian ini menggunakan dua sumber data yaitu data primer dan data sekunder. Data Primer adalah data yang diperoleh langsung melalui survei dan wawancara di desa pesisir Kabupaten Jember. Data Sekunder adalah data yang dikumpulkan melalui studi pustaka dan laporan-laporan dari instansi terkait. Populasi dalam penelitian ini adalah masyarakat yang berada di pesisir Kabupaten Jember, dan instansi-instansi yang terkait dalam pengembangan 
program pemberdayaan masyarakat pesisir. Adapun metode pengambilan sampel/responden yang dilakukan adalah dengan metode secara acak sengaja (penentuan sampel secara acak tapi dengan beberapa kriteria). Selanjutnya, pengambilan data untuk menentukan strategi pemberdayaan masyarakat pesisir Kabupaten Jember adalah menggunakan Focuss Group Discussion (FGD).

\section{HASIL PENELITIAN}

\section{Potensi Pesisir Kabupaten Jember}

a. Nelayan di Pesisir Kabupaten Jember.

Pesisir di Kabupaten Jember tidak semuanya terdapat kegiatan penangkapan sehingga masyarakat yang berprofesi sebagai nelayan-pun hanya ada di beberapa kecamatan di Jember diantaranya nelayan terdapat di Kecamatan Puger, Ambulu, Kencong, Gumukmas dan Tempurejo dengan jumlah nelayan di tahun 2017 sekitar 12.493. Jumlah tersebut menggunakan alat tangkap ikan jenis payang, gill net, trammel net, rawe dan jenis alat tangkap lainnya. Seperti pada tabel berikut mengenai rincian jumlah nelayan serta alat tangkap yang ada di Kabupaten Jember.
Selama tiga tahun terakhir jumlah nelayan di Kabupaten Jember menurun menjadi 12.494 nelayan. Dengan komposisi jumlah alat tangkap yang beroperasi cenderung stagnan, hanya pada alat tangkap jenis Trammel Net yang mengalami penurunan sekitar $50 \%$. Hal tersebut bisa menjadi indikator bahwa ikan hasil tangkapan mulai mengalami penurunan sehingga beberapa nelayan beralih mencari mata pencaharian yang lain.

b. Budidaya Ikan di Kabupaten Jember.

Potensi perikanan di Kabupaten Jember bukan hanya berpacu pada penangkapan ikan saja, melainkan menurut data dari Dinas Perikanan terdapat kegiatan budidaya ikan dengan jenis budidaya yaitu budidaya payau dan air tawar. Jenis budidaya air payau hanya pada jenis komoditas udang vanamei saja, sedangkan untuk budidaya air tawar terdapt beberapa jenis komoditas ikan diantaranya budidaya ikan gurami, tombro, nila/mujair, dan lele. Kegiatan budidaya tersebut tidak hanya tersebar di kawasan pesisir saja melainkan hampir se Kabupaten jember.

Budidaya payau yaitu udang berada di 3 kecamatan yaitu Kecamatan Gumukmas, Puger dan Ambulu. 
Artinya, yang bisa dilakukan pengembangan budidaya udang vanamei hanya di 3 kawasan pesisir itu saja sehingga hal itu tidak menjadi ukuran dalam pemberdayaan masyarakat pesisir khususnya untuk budidaya air payau. Namun untuk budidaya air tawar bisa menjadi program pemberdayaan masyarakat ke arah alternatif mata pencaharian dan peningkatan pendapatan masyarakat pesisir, mengingat produksi yang dihasilkan setiap tahunnya masih dalam angka yang cukup kecil sedangkan kebutuhan ikan konsumsi juga menjadi

trend peningkata saat ini bila dihubungkan dengan program pemerintah "Gemar Makan Ikan".

c. Terumbu Karang dan Mangrove Kabupaten Jember.

Potensi sumberdaya alam di kawasan pesisir Kabupaten Jember selain terdapat pantai yang langsung menghadap ke Samudera Hindia, juga terdapat potensi terumbu karang dan mangrove. Baik terumbu karang maupun mangrove tersebar di beberapa titik pesisir Kabupaten Jember seperti pada data yang diperoleh dari Dinas Perikanan Kabupaten Jember.
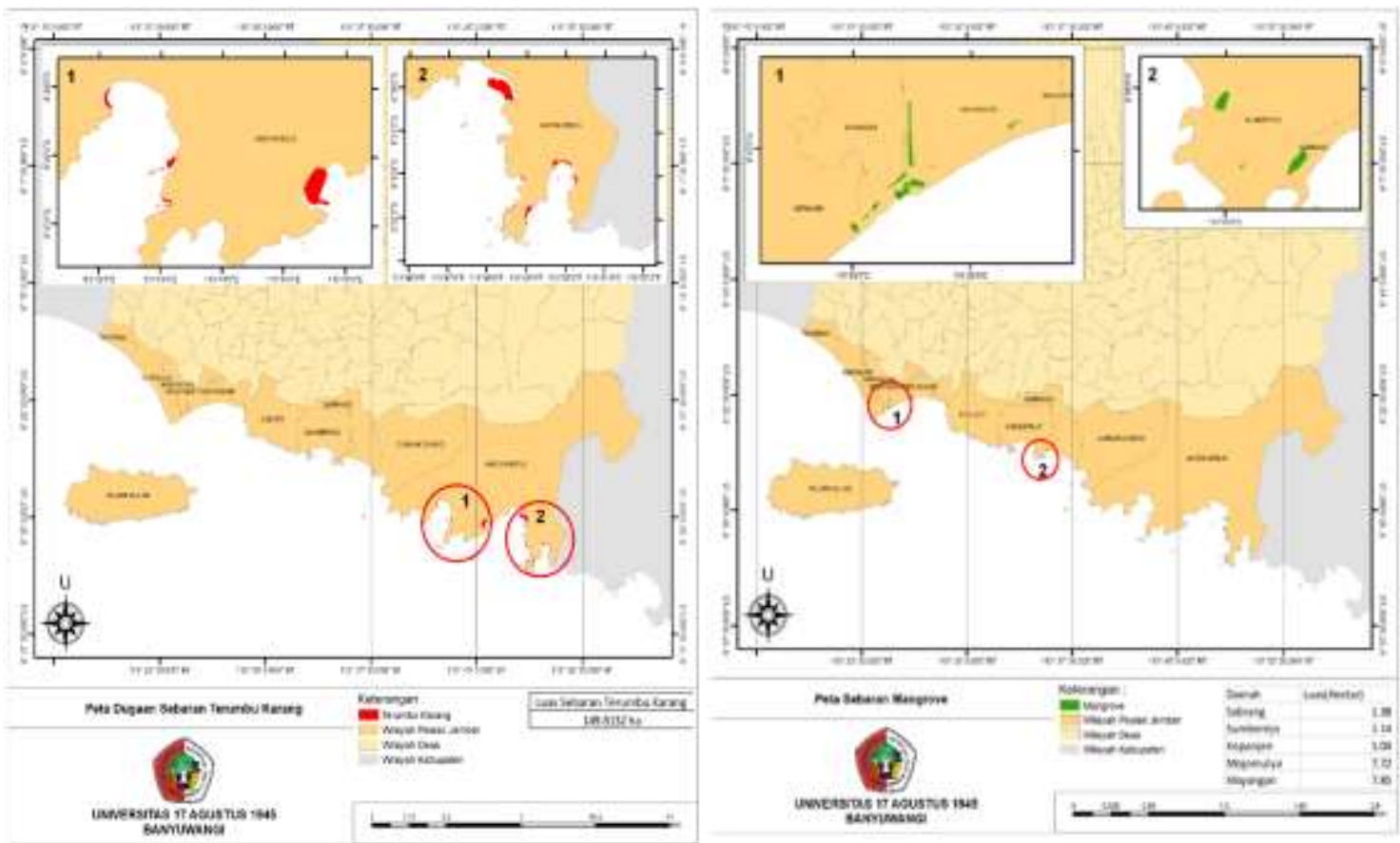

Gambar 1. Peta sebaran terumbu karang dan mangrove di Kabupaten Jember Tahun 2018.

Pemahaman Masyarakat terhadap Konsep Pesisir dan Pemberdayaan.

Survey dilakukan dengan metode wawancara kepada sample masyarakat pesisir di Kabupaten Jember, dengan fokus materi terkait dengan pelaksanaan pembangunan di kawasan pesisir dan pembinaan kemasyarakatan yang sudah 
dilakukan Pemerintah Kabupaten Jember. Responden yang berhasil diwawancarai terdiri dari beberapa jenis mata pencaharian seperti nelayan, pedagang ikan (wiraswasta), pedagang toko (wiraswasta/pengusaha kecil), petani ikan (pembudidaya), petani dan ibu rumah tangga.

\section{a. Pelaksanaan Pembangunan}

Kawasan Pesisir Kabupaten Jember.

Point ini menitik beratkan kepada pemahaman masyarakat akan pengertian pesisir itu sendiri beserta potensi pesisir khususnya yang ada di kawasan responden, serta istilah pemberdayaan dan jenis pemberdayaan yang ada di kawasan pesisir. Hasil survey menunjukkan $73 \%$ responden tidak paham akan konsep pesisir dan pemberdayaan sedangkan $27 \%$ sisanya yang mengetahui.

Berdasarkan hasil survey tersebut, menunjukkan mayoritas masyarakat yang berada di pesisir tidak memahami arti pesisir itu sendiri. Pesisir diartikan sebagai kawasan milik nelayan, padahal batas terluar sebelah hulu dari desa pantai atau jarak definitif secara arbiter (2 km, $20 \mathrm{~km}$ dari garis pantai/pasang tertinggi). Sehingga konsep pemberdayaan pesisir dianggap hanya untuk masyarakat nelayan saja, yang sebenarnya pemberdayaan pesisir adalah untuk dan melibatkan seluruh masyarakat yang berada di kawasan pesisir tersebut. Baik itu nelayan, petani, pedagang dan lain sebagainya yang tinggal di kawasan pesisir.

Ketidak pahaman akan konsep tersebut menjadi salah satu permasalahan besar dalam pengembangan kawasan pesisir khususnya yang terkait dengan kesejahteraan masyarakat. Karena nantinya menimbulkan ketidak perdulian masyarakat selain nelayan terhadap kawasannya sendiri. Definisi populasi masyarakat pesisir itu sendiri adalah kelompok orang yang tinggal di daerah pesisir dan sumber kehidupan perekonomiannya berantung secara langsung pada pemanfaatan sumberdaya laut dan pesisir. Pada dasarnya, banyak orang yang hidupnya bergantung pada sumberdaya laut, terdiri dari nelayan pemilik, buruh nelayan, pembudidaya ikan dan organisme laut lainnya, pedagang ikan, pengolah ikan, supplier, faktor sarana produksi perikanan. Dalam bidang non perikanan, masyarakat pesisir bisa terdiri dari penjual jasa pariwisata, penjual jasa transportasi, serta kelompok masyarakat lainnya yang memanfaatkan 
sumberdaya non-hayati laut dan pesisir untuk menyokong kehidupannya.

Masyarakat merupakan aktor utama dalam aktivitas pembangunan. Ini dikarenakan pembangunan dilakukan oleh masyarakat dan hasil dari pembangunan juga untuk masyarakat. Pembangunan yang berkualitas dan berkelanjutan adalah pembangunan yang mengutamakan masyarakat. Masyarakat adalah sumber daya yang sangat penting karena masyarakat mampu mengatur, menjaga, mengolah, dan mengelola sumber daya dan lingkungannya sehingga dapat memenuhi kebutuhannya. Peningkatan kesadaran masyarakat dalam pengelolaan sumber daya sangat penting demi keberlanjutan suatu wilayah (Ayunita \& Hapsari, 2012). Oleh karena itu, untuk mencapai pembangunan yang berkualitas dan berkelanjutan, diperlukan suatu kebijakan yang tepat untuk mengatur keseimbangan pembangunan pada aspek sosial, ekonomi dan lingkungan sehingga pembangunan di wilayah pesisir berada dalam status berkelanjutan.

Faktor yang menghambat wilayah pesisir dalam keberlanjutan aspek sosial adalah kegiatan sosial masyarakat yang belum maksimal dilaksanakan serta faktor pendidikan yang rendah sehingga pengetahuan masyarakat terhadap pemanfaatan sumber daya pesisir untuk meningkatkan perekonomian juga masih rendah (Arifiani, 2016). Hal tersebut mengakibatkan kurangnya perhatian masyarakat terhadap kelestarian lingkungan pesisir. Perilaku buruk masyarakat dalam membuang sampah menjadi penyebab penurunan kualitas lingkungan.

\section{b. Pembinaan Kemasyarakatan Kawasan Pesisir Kabupaten Jember. Pertanyaan yang disampaikan} kepada responden adalah terkait peran Pemerintah Kabupaten Jember dalam program pemberdayaan masyarakat pesisir, sejauh mana pemerintah memberikan pembinaan kepada masyarakat yang ada di kawasan pesisir. Hasil survey menunjukkan 92\% responden tidak mengetahui pernah ada program dari pemerintah yang berkaitan dengan pembinaan kemasyarakatan dalam hal ini seperti pemberdayaan masyarakat pesisir baik itu dalam bentuk sosialisasi, pelatihan maupun workshop. Sedangkan $8 \%$ sisanya yang mengetahui memang pernah teribat dalam program pembinaan dari pemerintah.

Hanya saja dalam keterangan yang disampaikan responden, 
pemerintah cenderung kurang bahkan tidak pernah mengajak masyarakat untuk berperan terhadap pengembangan kawasan masyarakat itu sendiri. Sehingga rasa keterlibatan masyarakat dalam pengawasan pelaksanaan pembangunan di kawasan pesisir juga cenderung acuh atau tidak perduli.

Kewajiban Pemerintah dalam memberikan perlindungan untuk kesejahteran masyarakat pesisir telah dituangkan ke dalam Pembukaan UUD Tahun 1945dengan tegas dinyatakan bahwa "Pemerintahan Negara Indonesia melindungi segenap bangsa Indonesia dan seluruh tumpah darah Indonesia dan untuk memajukan kesejahteraan umum, mencerdaskan kehidupan bangsa,...”. Hal ini mempunyai maksud bahwa Negara dalam hal ini Pemerintah berkewajiban dalam melindungi dan memberdayakan segenap seluruh warga Negara Inonesia termasuk masyarakat pesisir.

Peran pemerintah dalam hal ini adalah bahwa pemerintah wajib memberikan perlindungan dan pemenuhan atas kesejahteraan masyarakat khususnya pemberantasan kemiskinan. Namun secara realita, kehidupan masyarakat pesisir masih hidup dalam kemiskinan. Di sisi lain, pengelolaan lingkungan di wilayah pesisir memang tidak bisa dilepaskan dari kondisi riil mayarakat pesisir itu sendiri. Sehingga strategi yang diperlukan dalam pengelolaan lingkungan di wilayah pesisir adalah pengelolaan berbasis masyarakat (Dewi, 2016).

Tanggung jawab pembangunan masyarakat lebih banyak berada pada pundak pemerintah daerah, dan bukan didominasi oleh pemrintah pusat. Hal ini disebabkan karena pemerintah daerah lah yang lebih mengenal manyarakatnya, memahami masalahmasalah yang dihadapi. Selama ini, meskipun pada era desentralisasi dan otonomi daerah sekarang ini, ada kesan bahwa pengembangan masyarakat dilepaskan dan diserahkan kepada pemerintah pusat. Penyerahan tanggung jawab ini memang tugas pembangunan masyarakat termasuk berat untuk dilaksanakan. Dengan adanya desentralisasi kegiatan pembangunan, selayaknya dan sepatutnya pemerintah daerah lebih banyak memberikan prioritas pada pembangunan yang berbasis pada masyarakat.

Tanggung jawab pembangunan masyarakat pesisir bukan saja berada pada tangan pemerintah tetapi juga 
pihak-pihak non pemerintah yaitu masyarakat sendiri, pengusaha swasta, usaha milik negara, dan lembaga swadaya masyarakat. Tanggung jawab membangun masyarakat pada hakekatnya merupakan tanggung jawab itu sendiri. Selama ini, masyarakat semata-mata menjadi objek pembangunan. Dalam hubungan ini, masyarakat didekati, didatangi, diprogramkan, dan diarahkan untuk melaksanakan kegiatan-kegiatan yang nantinya membawa manfaat kepada mereka.

Pengelolaan wilayah pesisir yang berbasis masyarakat tentunya di masing-masing wilayah memiliki perbedaan. Hal ini sangat kental dipengaruhi oleh potensi, karakteristik dan nilai-nilai kearifan lokal masyarakat setempat. Dengan demikian pengelolaan wiayah pesisir yang dilakukan berbasis masyarakat tentunya berujung pada tercapainya kesejahteraan masyarakat pesisir, terutama mengurangi angka kemiskinan pada masyarakat pesisir (Dewi, 2016). Berkenaan dengan keberadaan masyarakat yang ada di wilayah pesisir dan sebagai masyarakat yang menggantungkan kehidupannya pada ekosistem laut yang berdasarkan pada hukum adatnya, maka perlu dilakukan pengelolaan lingkungan di wilayah laut dan pantai dilakukan secara terpadu. Pengelolaan lingkungan secara terpadu berdampak pada pengelolaan efektif untuk penyeimbang pemanfaatan ekonomi dan pelestarian lingkungan. Berdasarkan penyeimbang pemanfaatan tersebut memungkinkan timbulnya bentuk-bentuk pengelolaan lain yang lebih aplikatif (applicable) dan adaptif (acceptable). Salah satu bentuk pengelolaan yang lebih aplikatif dan adaptif dalam pengelolaan adalah pengelolaan wilayah pesisir yang berbasis masyarakat (community based management).

Ada lima pendekatan pemberdayaan masyarakat pesisir yang baru saja diimplementasikan. Kelima pendekatan tersebut adalah: 1) penciptaan lapangan kerja alternatif sebagai sumber pendapatan lain bagi keluarga, 2) mendekatkan masyarakat dengan sumber modal dengan penekakan pada penciptaan mekanisme mendanai diri sendiri (self financing mechanism), 3) mendekatkan masyarakat dengan sumber teknologi baru yang lebih berhasil dan berdaya guna, 4) mendekatkan masyarakat dengan pasar, serta 5) membangun solidaritas serta aksi kolektif di tengah 
masyarakat. Kelima pendekatan ini dilaksanakan dengan emmperhatikan secara sungguh-sungguh aspirasi, keinginan, kebutuhan, pendapatan dan potensi sumberdyaa yang dimiliki masyarakat (Pamungkas dan Rahmawati, 2017).

Analisa SWOT (Strategi Pemberdayaan Masyarakat Pesisir). Analisa lanjutan yang dilakukan dalam penelitian ini, setelah identifiksi permasalahan diketahui adalah analisa SWOT untuk menentukan strategi pemberdayaan masyarakat pesisir Kabupaten Jember. Dalam hal ini, data yang telah dikumpulkan menggunakan focus group discussion (FGD) dan kemudian menjadi input dalam menentukan faktor internal maupun eksternal.

FGD yang dilakukan, melibatkan beberapa steakholder diantaranya
Perwakilan Kecamatan yang ada di kawasan pesisir yaitu Kecamatan Kencong, Puger, Wuluhan, Ambulu, Tempurejo, kemudian Dinas Koperasi, Dinas Perikanan, Taman Nasional Meru Betiri, Bappeda, Dinas Pemberdayaan Desa. Hasil FGD dan wawancara yang dilakukan, maka dirumuskan beberapa poin yang menjadi masukan dalam pembuatan matriks internal strategic factor analysis summary (IFAS) dan external strategic factor analysis summary (EFAS). Analisis faktor internal dimaksudkan untuk memahami kekuatan dan kelemahan yang dimiliki dalam penentuan strategi pemberdayaan masyarakat pesisir Kabupaten Jember. Aspek yang dianalisis pada lingkungan internal antara lain sumberdaya ikan, sumberdaya manusia, fasilitas. Adapun hasil perumusan yang telah dilakukan saat FGD adalah sebagai berikut.

Tabel 1. Matriks IFAS - Faktor Kekuatan.

\begin{tabular}{|c|c|c|c|c|}
\hline No. & Variabel Kekuatan (Streghts) & Bobot & Rating & Skor \\
\hline 1. & Memiliki pantai & 0,0275 & 4 & 0,11 \\
\hline 2. & $\begin{array}{l}\text { Memiliki potensi sumberdaya ikan dan penangkapan } \\
\text { ikan }\end{array}$ & 0,0825 & 2 & 0,165 \\
\hline 3. & Memiliki mangrove & 0,165 & 4 & 0,66 \\
\hline 4. & Terdapat tanaman cemara & 0,11 & 3 & 0,33 \\
\hline 5. & $\begin{array}{l}\text { Terdapat hutan di kawasan Perhutani dan Taman } \\
\text { Nasional Meru Betiri }\end{array}$ & 0,1475 & 4 & 0,59 \\
\hline 6. & $\begin{array}{l}\text { Terdapat budidaya udang vanamae, budidaya air tawar } \\
\text { (lele) }\end{array}$ & 0,055 & 1 & 0,055 \\
\hline 7. & $\begin{array}{l}\text { Terdapat pengolahan ikan hasil perikanan (terasi, } \\
\text { kerupuk ikan, pemindangan, pengasinan) }\end{array}$ & 0,0825 & 2 & 0,165 \\
\hline 8. & $\begin{array}{l}\text { Memiliki potensi pertanian (Tembakau, Cabe, } \\
\text { Semangka, Pepaya, Padi, Jagung, Kacang tanah) }\end{array}$ & 0,1375 & 4 & 0,55 \\
\hline \multirow[t]{2}{*}{9.} & Terdapat kelompok masyarakat & 0,1925 & 3 & 0,5775 \\
\hline & Total Skor Kekuatan/Streghts & 1 & & 3,2025 \\
\hline
\end{tabular}


Tabel 2. Matriks IFAS - Faktor Kelemahan.

\begin{tabular}{|c|c|c|c|c|}
\hline No. & Variabel Kelemahan (Weaknesses) & Bobot & Rating & Skor \\
\hline 1. & $\begin{array}{l}\text { Mayoritas masyarakat pesisir tidak memahami potensi } \\
\text { pesisir dan konsep pemberdayaan }\end{array}$ & 0,146 & -4 & $-0,584$ \\
\hline 2. & TPI tidak berfungsi & 0,063 & -2 & $-0,126$ \\
\hline 3. & Sebagian kapal tidak memiliki surat ijin & 0,021 & -1 & $-0,021$ \\
\hline 4. & $\begin{array}{l}\text { Fungsi KUB kurang optimal terhadap nelayan secara } \\
\text { keseluruhan }\end{array}$ & 0,042 & -4 & $-0,168$ \\
\hline 5. & Akses jalan menuju mayoritas kawasan pesisir/pantai sulit & 0,125 & -4 & $-0,5$ \\
\hline 6. & Pelatihan kepada nelayan tidak ada di tahun 2018 & 0,021 & -2 & $-0,042$ \\
\hline 7. & $\begin{array}{l}\text { Sosialisasi dan pelatihan tidak merata hanya pada orang } \\
\text { tertentu }\end{array}$ & 0,146 & -3 & $-0,438$ \\
\hline 8. & Tidak semua masyarakat setuju dengan konsep konservasi & 0,063 & -4 & $-0,252$ \\
\hline 9. & Mangrove belum teridentifikasi jenis dan kerapatannya & 0,125 & -3 & $-0,375$ \\
\hline 10. & $\begin{array}{l}\text { Belum terintegrasi kepentingan masyarakat pesisir dengan } \\
\text { Pemerintah Desa, Kecamatan dan Kabupaten, sehingga } \\
\text { pembangunan pesisir stagnan }\end{array}$ & 0,083 & -4 & $-0,332$ \\
\hline 11. & $\begin{array}{l}\text { Pengembangan teknologi dan modal pada pengembangan } \\
\text { usaha UMKM di kawasan pesisir belum merata dan } \\
\text { terintegrasi }\end{array}$ & 0,123 & -2 & $-0,246$ \\
\hline 12. & $\begin{array}{l}\text { Terdapat konflik kepentingan perbatasan di beberapa } \\
\text { kawasan pesisir }\end{array}$ & 0,042 & -4 & $-0,168$ \\
\hline & Total Skor Kelemahan/Weaknesses & \multicolumn{2}{|l|}{1} & $-3,252$ \\
\hline
\end{tabular}

\section{Analisis faktor internal}

dimaksudkan untuk memahami peluang

dan ancaman yang dimiliki dalam

penyusunan strategi pemberdayaan

masyarakat pesisir Kabupaten Jember.

Aspek yang dianalisis pada lingkungan eksternal antara lain yang dimiliki lembaga/sistem,

diantaranya

mengidentifikasi aspek pemerintah, kebijakan, dan teknologi. Adapun hasil perumusan yang telah dilakukan saat FGD adalah sebagai berikut.

Tabel 3. Matriks EFAS - Faktor Peluang.

\begin{tabular}{|c|c|c|c|c|}
\hline No. & Variabel Peluang (Opportunity) & Bobot & Rating & Skor \\
\hline 1. & Dikembangkan wisata pantai di beberapa titik pesisir & 0,2125 & 4 & 0,85 \\
\hline 2. & $\begin{array}{l}\text { Dikembangkan wisata hutan di lingkungan Perhutani } \\
\text { dan Taman Nasional Meru Betiri }\end{array}$ & 0,2125 & 4 & 0,85 \\
\hline 3. & Dikembangkan wisata mangrove & 0,125 & 4 & 0,5 \\
\hline 4. & Dikembangkan wisata pertanian (Agrowisata) & 0,125 & 4 & 0,5 \\
\hline 5. & $\begin{array}{l}\text { Optimalisasi KUB dan pengembangan ke arah mata } \\
\text { pencaharian alternatif }\end{array}$ & 0,075 & 3 & 0,225 \\
\hline 6. & $\begin{array}{l}\text { Pengembangan koperasi ke seluruh kawasan pesisir } \\
\text { untuk kelompok masyarakat }\end{array}$ & 0,075 & 3 & 0,225 \\
\hline 7. & $\begin{array}{l}\text { Pembangunan sarana prasarana seperti akses jalan } \\
\text { menuju kawasan pesisir }\end{array}$ & 0,075 & 3 & 0,225 \\
\hline 8. & $\begin{array}{l}\text { Pengolahan hasil perikanan untuk mendapatkan value } \\
\text { added khususnya saat panen tiba ataupun paceklik. }\end{array}$ & 0,05 & 2 & 0,1 \\
\hline 9. & $\begin{array}{l}\text { Pengolahan hasil mangrove menjadi sirup mangrove, } \\
\text { peyek mangrove, kopi dan teh mangrove, dll. }\end{array}$ & 0,025 & 1 & 0,025 \\
\hline 10. & $\begin{array}{l}\text { Optimalisasi Tambak/budidaya air payau (udang } \\
\text { vanamae) dan tawar (ikan lele) }\end{array}$ & 0,025 & 1 & 0,025 \\
\hline
\end{tabular}


Tabel 4. Matriks EFAS - Faktor Ancaman.

\begin{tabular}{|c|c|c|c|c|}
\hline No. & Variabel Ancaman (Threats) & Bobot & Rating & Skor \\
\hline 1. & $\begin{array}{l}\text { Abrasi pesisir di beberapa kawasan pantai akibat arus } \\
\text { deras }\end{array}$ & $\overline{0,2}$ & -3 & $-0,6$ \\
\hline 2. & $\begin{array}{l}\text { Wisata Pantai tidak berkelanjutan karena masyarakat } \\
\text { malas menuju ke pantai akibat akses jalan yang } \\
\text { buruk/rusak dan tidak ada road sign yang jelas menuju } \\
\text { kawasan pantai }\end{array}$ & 0,35 & -4 & $-1,4$ \\
\hline 3. & $\begin{array}{l}\text { Prinsip konservasi mangrove mengalami degradasi } \\
\text { karena terkendala dana operasional. }\end{array}$ & 0,1 & -2 & $-0,2$ \\
\hline 4. & $\begin{array}{l}\text { Terpecahnya kepentingan kelompok masyarakat karena } \\
\text { tidak ada integrasi kepentingan semua lini masyarakat. }\end{array}$ & 0,3 & -3 & $-0,9$ \\
\hline \multirow[t]{2}{*}{5.} & $\begin{array}{l}\text { Beberapa UMKM akan gulung tikar akibat kekurangan } \\
\text { modal usaha. }\end{array}$ & 0,05 & -1 & $-0,05$ \\
\hline & Total Skor Ancaman/ Threats & 1 & & $-3,15$ \\
\hline
\end{tabular}

Selanjutnya berdasarkan hasil evaluasi faktor internal yaitu faktor kekuatan dan kelemahan, serta faktor eksternal yaitu faktor peluang dan ancaman, maka analisa grand strategy adalah sebagai berikut:

Jumlah nilai faktor internal

$=$ Skor IFAS Kekuatan/Streghts + Skor IFAS Kelemahan/Weaknesses

$$
\begin{aligned}
& =3,2025+(-3,252) \\
& =-0,0495
\end{aligned}
$$

Jumlah nilai faktor eksternal

$=$ Skor IFAS Peluang/Opportunity + Skor IFAS Ancaman/Threats

$$
\begin{aligned}
& =3,525+(-3,15) \\
& =0,375
\end{aligned}
$$

\section{Hasil perhitungan skor faktor} internal dan eksternal digunakan untuk menentukan titik koordinat strategi. Dalam hal ini sebagai sumbu " $x$ " adalah skor faktor internal, sedangkan sumbu "y" adalah skor faktor eksternal.
Jadi koordinat grand strategi untuk analisa SWOT adalah (-0,0495, 0,375) berada di kuadran II yaitu menggambarkan situasi bahwa meskipun organisasi menghadapi ancaman, namun ada kekuatan yang dapat diandalkan. Untuk itu dalam penentuan strategi pemberdayaan masyarakat pesisir Kabupaten Jember, point organisasi dapat menggunakan alternatif strategi 2 yakni strategi diversifikasi atau strategi inovasi. Kuadran kedua ini menggambarkan kondisi internal yang lemah dan kurang mendukung sehingga arah, sasaran dan strategi organisasi yang sesuai adalah yang bersifat perbaikan

intern, misalnya stabilisasi dan rasionalisasi. 


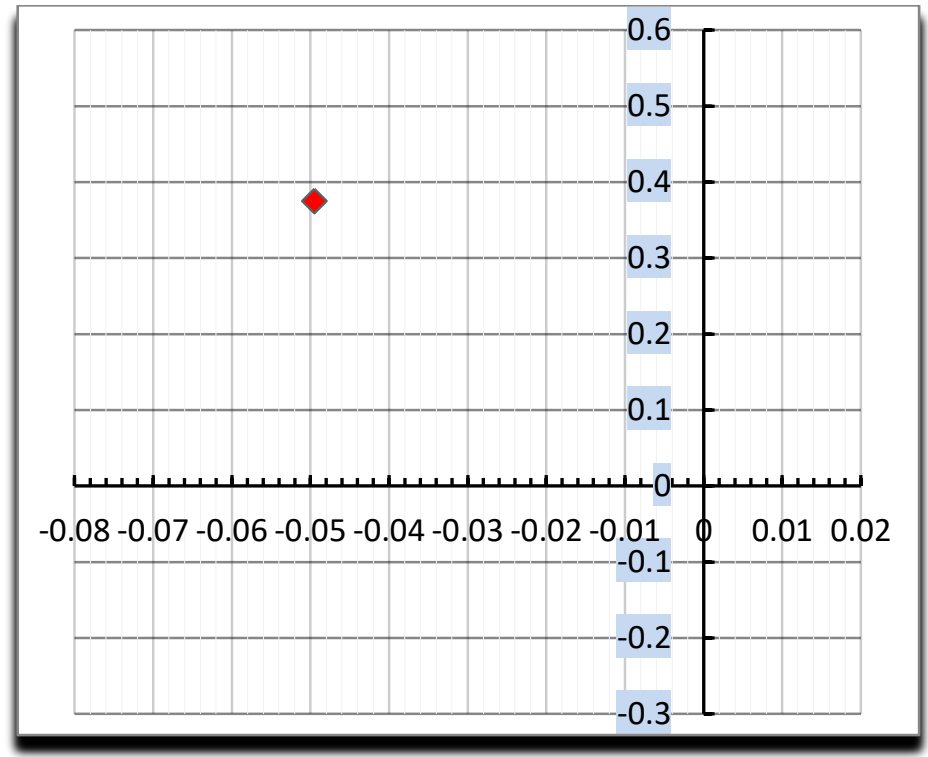

Gambar 2. Kwadran Analisis SWOT (Strategi Pemberdayaan Masyarakat Pesisir Kabupaten Jember).

\section{Dari Matriks IFAS dan EFAS} yang telah dibuat, kemudian dirangkum dalam Matriks SWOT untuk memberikan rumusan alternatif strategi kebijakan yang sesuai bagi pemberdayaan masyarakat pesisir
Kabupaten Jember. Penyusunan rumusan strategi adalah dari perpaduan faktor SWOT yang telah dikembangkan dalam Matriks IFAS dan EFAS. Perpaduan Matriks SWOT tersebut dapat dilihat pada tabel berikut ini.

Tabel 5. Grand Strategy Pemberdayaan Masyarakat Pesisir Kabupaten Jember.

\begin{tabular}{|c|c|c|}
\hline IFAS/EFAS & Strengths (S) & Weakness (W) \\
\hline $\begin{array}{l}\text { Opportunities } \\
\text { (O) }\end{array}$ & $\begin{array}{l}\text { Rekomendasi SO : } \\
\text { Peningkatan pengetahuan dan teknologi pada } \\
\text { masyarakat tentang konsep pesisir dan } \\
\text { pemberdayaan masyarakat (khususnya } \\
\text { partisipasi masyarakat) untuk menciptakan } \\
\text { mata pencaharian alternatif berbasis } \\
\text { sumberdaya alam, sehingga menghasilkan } \\
\text { produk bernilai tambah yang berkelanjutan } \\
\text { (ekologisosiografi). }\end{array}$ & $\begin{array}{l}\text { Rekomendasi WO : } \\
\text { Perbaikan akses jalan menuju kawasan pesisir } \\
\text { (khususnya pantai) Kabupaten Jember serta } \\
\text { beberapa sarana prasarana untuk menunjang } \\
\text { pengembangan ekowisata Pantai; } \\
\text { Penguatan kelembagaan kelompok masyarakat; } \\
\text { Pengembangan sarana dan prasarana pelabuhan } \\
\text { perikanan (tempat pendaratan ikan). }\end{array}$ \\
\hline Threats (T) & $\begin{array}{l}\text { Rekomendasi ST : } \\
\text { Optimalisasi Kepengurusan KUB di pesisir } \\
\text { Kabupaten Jember sebagai dasar } \\
\text { pengembangan, pengelolaan serta pengaturan } \\
\text { kawasan pesisir dan ekowisata pantai yang } \\
\text { berkelanjutan, dan berbasis partisipasi } \\
\text { masyarakat. }\end{array}$ & $\begin{array}{l}\text { Rekomendasi WT : } \\
\text { Identifikasi potensi sumberdaya pesisir dan } \\
\text { kebutuhan masyarakat pesisir yang berkelanjutan; } \\
\text { Deliniasi kawasan pesisir antar desa dalam } \\
\text { wilayah kecamatan; } \\
\text { Integrasi program pemberdayaan masyarakat } \\
\text { pesisir antar stakeholder (horizontal atau vertikal) }\end{array}$ \\
\hline
\end{tabular}


pemberdayaan masyarakat pesisir Kabupaten Jember melalui analisa SWOT dengan pengambilan data menggunakan focus group discussion, maka dihasilkan fokus strategi masuk pada kuadran II yaitu menggambarkan situasi bahwa meskipun organisasi menghadapi ancaman, namun ada kekuatan yang dapat diandalkan, hal ini menggambarkan kondisi internal yang lemah dan kurang mendukung sehingga arah, sasaran dan strategi organisasi yang sesuai adalah yang bersifat perbaikan

intern, misalnya stabilisasi dan rasionalisasi. Sedangkan grand strategi yang dirumuskan adalah sebagai berikut:

a. Peningkatan pengetahuan dan teknologi pada masyarakat tentang konsep pesisir dan pemberdayaan masyarakat (khususnya partisipasi masyarakat) untuk menciptakan mata pencaharian alternatif berbasis sumberdaya alam, sehingga menghasilkan produk bernilai tambah yang berkelanjutan (ekologisosiografi).

b. Perbaikan akses jalan menuju kawasan pesisir (khususnya pantai) Kabupaten Jember serta beberapa sarana prasarana untuk menunjang pengembangan ekowisata pantai.

c. Penguatan kelembagaan kelompok masyarakat sebgai langkah optimalisasi kepengurusan kelompok usaha bersama (KUB) di pesisir Kabupaten Jember sebagai dasar pengembangan, pengelolaan serta pengaturan kawasan pesisir dan ekowisata pantai yang berkelanjutan, dan berbasis partisipasi masyarakat.

d. Pengembangan sarana dan prasarana pelabuhan perikanan (tempat pendaratan ikan).

e. Identifikasi potensi sumberdaya pesisir dan kebutuhan masyarakat pesisir yang berkelanjutan.

f. Deliniasi kawasan pesisir antar desa dalam wilayah kecamatan.

g. Integrasi program pemberdayaan masyarakat pesisir antar stakeholder (horizontal atau vertikal).

\section{DAFTAR PUSTAKA}

Ayunita, D. N. \& Hapsari, T. D. (2012). Analisis persepsi dan partisipasi masyarakat pesisir pada pengelolaan KKLD Ujungnegoro Kabupaten Batang. SEPA , 9 (1): 117-124.

Arifiani Nikken Adita. 2016. Studi Persepsi Masyarakat terhadap Tingkat Keberlanjutan Wilayah Pesisir Kecamatan Sarang. JURNAL WILAYAH DAN LINGKUNGAN, 4 (3): 171-186

Dewi Anak Agung Istri Ari Atu. 2016. Model Pengelolaan Wilayah Pesisir Berbasis Masyarakat: Community Based 
Journal of Aquaculture Science

DOI: https://doi.org/10.31093/joas.v6i1IS.178
July 2021 Vol 6 Issue Spesial: 245-260

Online pada http://joas.co.id

Development. Jurnal Penelitian Hukum

DE JURE, Vol. 18 (2): 163 - 182

Pamungkas Adjie dan Rahmawati Dian. 2017.

Perencanaan Kawasan Pesisir Terpadu

di Indonesia. Teori dan Praktek.

Teknosain, Yogyakarta. 